\title{
Influence of particle size on appearance and in vitro efficacy of sunscreens
}

\author{
Débora Granemann e Silva ${ }^{1, *}$, Fernanda Daud Sarruf ${ }^{1}$, Larissa Carolina Diniz de Oliveira ${ }^{1}$, \\ Elizabeth Pinheiro Gomes Arêas ${ }^{2}$, Telma Mary Kaneko', Vladi Olga Consiglieri' ${ }^{1}$, \\ Maria Valéria Robles Velasco ${ }^{1}$, André Rolim Baby ${ }^{1}$
}

\author{
${ }^{1}$ Department of Pharmacy, Faculty of Pharmaceutical Sciences, University of São Paulo, ${ }^{2}$ Department of Fundamental \\ Chemistry, Institute of Chemistry, University of São Paulo
}

\begin{abstract}
Nanotechnology applies to diverse sectors of science. In cosmetic area, investments have strengthened the idea that nanoproducts provide innumerable benefits to consumers. Extreme exposition to solar light can cause undesirable effects, thus, adding UV filters in cosmetic products are often used as prevention. Ethylhexyl methoxycinnamate and benzophenone-3 are UV filters widely used in sunscreen formulations, this UV filters absorb UVB and UVA radiation, respectively. In this study, sunscreen formulations were developed as nano and macroemulsion, but composed by the same raw material. Nanoemulsion was obtained by phase inversion temperature method (PIT). Physical and functional properties were evaluated by visual analysis, particle size distribution and by diffuse reflectance spectrophotometry. Achieved nanoemulsion showed bluish brightness aspect, less apparent consistency than macroemulsion, stability longer than 48 hours $\left(22.0 \pm 2.0^{\circ} \mathrm{C}\right)$ and bimodal particle size distribution with average (mean) sizes around $10 \mathrm{~nm}(61 \%)$ and $4.5 \mu \mathrm{m}(39 \%)$. Macroemulsion showed milky aspect, higher consistency than nanoemulsion, instability after 48 hours $\left(22.0 \pm 2.0^{\circ} \mathrm{C}\right)$ and bimodal particle size distribution with average (mean) size around 202 $\mathrm{nm}(9 \%)$ and $10.4 \mu \mathrm{m}(91 \%)$. Effectiveness profile of sunscreen formulations remained apparently similar, based on achieved results of in vitro SPF, UVA/UVB ratio and critical wavelength assays.
\end{abstract}

Uniterms: Nanoemulsion. PIT method. Benzophenone-3. Ethylhexyl methoxycinnamate.

A nanotecnologia se aplica a diversos setores da ciência. Na área de cosméticos, os investimentos têm reforçado a idéia de que nanoprodutos oferecem inúmeros benefícios para os consumidores. A exposição excessiva à luz solar pode causar efeitos indesejáveis, logo, a adição de filtros UV em produtos cosméticos é frequentemente usada como prevenção. O p-metoxicinamato de octila e a benzofenona-3 são filtros UV amplamente utilizados em formulações de protecção solar, que absorvem radiações UVB e UVA, respectivamente. Neste estudo, desenvolveram-se formulações de protetores solares na forma de nano e macroemulsão, mas compostos pelas mesmas matérias-primas. A nanoemulsão foi obtida pelo método da temperatura de inversão de fases (PIT). As propriedades físicas e funcionais foram avaliadas por análise visual, distribuição de tamanho de partículas e por espectrofotometria de reflectância difusa. Ananoemulsão obtida apresentou brilho azulado, menor consistência aparente quando comparada `a macroemulsão, estabilidade superior a 48 horas $\left(22,0 \pm 2,0^{\circ} \mathrm{C}\right)$ e distribuição de tamanhos de partícula bimodal, com média (média) de tamanhos ao redor de $10 \mathrm{~nm}(61 \%)$ e $4,5 \mu \mathrm{m}(39 \%)$. A macroemulsão apresentou aspecto leitoso, maior consistência aaprente do que nanoemulsão, instabilidade após 48 horas $\left(22,0 \pm 2,0^{\circ} \mathrm{C}\right) \mathrm{e}$ distribuição de tamanhos de partícula bimodal, com média (média) de tamanhos ao redor de $202 \mathrm{~nm}$ (9\%) e $10,4 \mu \mathrm{m}(91 \%)$. O perfil de eficácia das formulações fotoprotetoras permaneceu aparentemente similar, com base em resultados obtidos por ensaios de FPS in vitro, relação UVA/UVB e comprimento de onda crítico.

Unitermos: Nanoemulsão. Método PIT. Benzofenona-3. p-Metoxicinamato de octila.

\footnotetext{
*Correspondence: D. G. Silva. Departamento de Farmácia, Faculdade de Ciências Farmacêuticas, Universidade de São Paulo. Av. Prof. Lineu Prestes, 580, Conj. das Químicas, Bloco 15, 05508-000, São Paulo, SP, Brasil. E-mail: debora@neerven.com
} 


\section{INTRODUCTION}

Nowadays, considerable part of available cosmetic products world-wide are nanotechnology based. Interest in nanotechnology for development of these products inhabits in the possibility of properties improvement, like smoother spread feeling, uniform deposition on skin and improvement of covering ability (Fronza et al., 2007; Tadros et al., 2004). One characteristic of nanoemulsions is a bluish brightness and translucent aspect, whereas macro emulsions display milky appearance (Mason et al., 2006). Furthermore, nanoemulsions are metastable systems, which mean they are able to remain themselves steady for a long period of time, if not disturbed. Moreover, their structure depends on the preparation process (Fernandez et al., 2004; Capek, 2004).

It is well established that sun exposure is the main cause for some undesirable effects like burnings and skin cancer. In this respect sunscreens have proved their importance and justified popularity within the last decades. Currently, there is a trend for broad-spectrum sunscreens, high sun protection factor (SPF) and concentration reduction of UV filters (Maier, Korting, 2005).

In the 1980's, benzophenone-3 became the most common component in sunscreen formulations worldwide. It acts absorbing, UVB radiation (290-320 $\mathrm{nm})$ and UVA radiation (320-400 $\mathrm{nm}$ ) from sunlight. Although reactions to benzophenone-3 are not representative for organic sunscreens, in general sunscreen formulations can induce photo-contact allergic reactions (Schauder, Ippen, 1997). Currently, the maximum allowed concentration of this substance in Brazilian and European sunscreen formulations is $10 \%$ (Brazil, 2006; EEC, 1976). Another UV filter frequently used in sunscreen formulations is ethylhexyl methoxycinnamate an organic UV filter that acts absorbing UVB radiation $(290-320 \mathrm{~nm})$ from sunlight (Pattanaargson et al., 2004). In accordance with Brazilian and European current legislation the allowed maximum concentration of this substance in sunscreen formulations is $10 \%$ (Brazil, 2006; EEC, 1976).

In this study, sunscreen formulations were developed as nano and macroemulsions, composed by the same raw material and both emulsions were characterized by physical and functional assays.

\section{MATERIAL AND METHODS}

\section{Material}

Both emulsions, nano and macro, were composed of the same raw materials: BHT (Mapric), disodium EDTA
(Mapric), phenoxyethanol (and) methylparaben (and) ethylparaben (and) propylparaben (and) butylparaben (and) isobutylparaben (Phenova ${ }^{\mathrm{TM}}$, Croda), sodium chloride (Mapric), glycerin (Mapric), cetearyl alcohol (Mapric), acqua, ethylhexyl methoxycinnamate (Mapric), benzophenone-3 (Mapric), caprylic/capric triglyceride (Croda), oleth-3 (Brij ${ }^{\mathrm{TM}} \mathrm{O} 3$, Croda) and oleth-20 (Brij ${ }^{\mathrm{TM}} \mathrm{O} 20$, Croda). Raw materials were of pharmaceutical grade and they were obtained from commercial sources, used without any further purification.

In vitro sun protection assessment was performed by a spectrophotometer (Ultraviolet Transmittance Analyzer, UV-2000s, Labsphere, US). As substrate, Poly (methylmethacrylate) (PMMA) plate (HD Helioplate ${ }^{\mathrm{TM}}$, from HelioScreeen, US) was used.

\section{Methods}

\section{Qualitative and quantitative (\% $w / w)$ composition of the emulsions}

Emulsions, nano and macro, were equally composed and both contained the UV filters benzophenone- 3 and ethylhexyl methoxycinnamate. Qualitative and quantitative $(\% \mathrm{w} / \mathrm{w})$ compositions are described in Table I.

TABLE I - Qualitative and quantitative ( $\% \mathrm{w} / \mathrm{w})$ composition of the emulsified systems (macro and nanoemulsions)

\begin{tabular}{lc}
\hline COMPOUNDS (INCI Name) & $\%$ (w/w) \\
\hline BHT & 0.1 \\
Disodium EDTA & 0.1 \\
Phenoxyethanol (and) methylparaben (and) & 0.5 \\
ethylparaben (and) propylparaben (and) & \\
butylparaben (and) isobutylparaben & \\
Sodium chloride & 1.0 \\
Glycerin & 5.0 \\
Cetearyl alcohol & 3.0 \\
Acqua & q.s. \\
Ethylhexyl methoxycinnamate & 7.5 \\
Benzophenone-3 & 2.0 \\
Caprylic/capric triglyceride & 5.0 \\
Oleth-3 & 2.0 \\
Oleth-20 & 10.0 \\
\hline
\end{tabular}

Nano and macro emulsions were prepared using the phase inversion temperature (PIT) method (Izquierdo et al., 2005; Ee et al., 2008). Firstly, it was necessary to determine the hydrophilic-lipophilic balance (HLB) 
temperature, also defined as phase inversion temperature (PIT), using the electrical conductivity method. All compounds (Table I) were weighed in a glass beaker and then heated gradually while the conductivity was measured as a function of temperature. The PIT temperature was determined as the temperature at which the conductivity decreases sharply, corresponding to a phase inversion from oil-in-water to water-in-oil emulsion (PIT $=72.0-75.0^{\circ} \mathrm{C}$, data not shown). Then, to preparer the nanoemulsion, all compounds (Table I) were weighed again in another glass beaker and heated up to the PIT. Once the PIT was reached, the system was removed from heating source and cooled down in water bath until room temperature $\left(22.0 \pm 2.0{ }^{\circ} \mathrm{C}\right)$. Mechanical agitation of $400 \mathrm{rpm}$ was kept during the heating and cooling process. For macroemulsion preparation, all compounds were weighed in a glass beaker and heated up to $5.0{ }^{\circ} \mathrm{C}$ below the PIT. After this step, the system was removed from heating source and cooled down in water bath until room temperature $\left(22.0 \pm 2.0{ }^{\circ} \mathrm{C}\right)$. Mechanical agitation of $400 \mathrm{rpm}$ was kept during the heating and cooling process. The differences in the heating temperature between the two methods produce different emulsions due to the high dependence on temperature when using ethoxylate nonionic surfactants (Tadros et al., 2004). Thus, emulsions were stored 24 hours before assays were performed.

\section{Particle size and size distribution}

The particle size and size distribution were measured with an acoustic spectrometer (DT-1200, Dispersion Technology Inc., Bedford Hills, NY). The operating principle of acoustic spectroscopy is based on the generation of sound pulses that pass through a sample and are measured by a receiver. During the passage through the sample, sound is attenuated by the presence of the liquid medium and any particles in dispersion, and the energy changes in intensity and phase are measured (Bonacucina et al., 2009; Sun et al., 2006; Dukhin et al., 2001; Dukhin, Goetz, 2002).

In this study, a sample of each emulsion (nano and macro) was prepared, stored 24 hours and then placed separately into the DT-1200 (Dispersion Technology Inc., Bedford Hills, NY) without dilution. Analysis were performed three times, in the gap interval of $0.325-20 \mathrm{~mm}$ between transmitter and receiver and in the frequency range of 3-100 MHz. Sound attenuation and speed were monitored over time.

\section{In vitro sun protection assessment}

In vitro sun protection assessment of emulsions, nano and macro, were performed by a spectrophotometer equipped with an integrating sphere detector (Ultraviolet Transmittance Analyzer, UV-2000S, Labsphere, US). As substrate, poly ( methylmethacrylate) (PMMA) plate (HD Helioplate ${ }^{\mathrm{TM}}$, from HelioScreeen, US) was used. Emulsions samples were prepared, stored 24 hours and then uniformly applied on the roughened side of the substrate, PMMA plate. The emulsion film $\left(0.75 \mathrm{mg} / \mathrm{cm}^{2}\right)$ was then allowed to dry under ambient conditions $\left(22.0 \pm 2.0{ }^{\circ} \mathrm{C}\right)$ for 30 minutes. UV absorbance of the emulsion film was measured at nine different sites on the substrate. The resulting absorbance was used to determine in vitro $\mathrm{SPF}$, critical wavelength $(\lambda \mathrm{c})$ and $\mathrm{UVA} / \mathrm{UVB}$ ratio. Those parameters were automatically calculated by the equipment software, UV2000 (Comité de Liaison des Industries de la Parfumerie, 2007; Couteau et al., 2007; Ferrero et al., 2006; Ferrero et al., 2010; Pissavini et al., 2003; Springsteen et al., 1999; Velasco et al., 2008).

\section{RESULTS AND DISCUSSION}

The achieved nanoemulsion showed bluish brightness appearance, different from the macroemulsion, which showed milky aspect (Figure 1). According to Mason and colleagues (2006), nanoemulsions appear visibly different from macroemulsions since the droplets can be much smaller than optical wavelengths of the visible spectrum. The smaller the droplet radius, broader is the range of visible wavelengths over which the transparency is found, especially toward the blue and ultraviolet wavelengths. However, as the droplet radius approaches $100 \mathrm{~nm}$, nanoemulsions appear hazy, and above this, they appear white due to significant multiple scattering. Optical transparency is also a good qualitative indicator of significant polydispersity since any extension of the size distribution toward microscale droplet sizes will make the nanoemulsion appear hazy, even if the vast majority of the droplets are truly nanoscale (Mason et al., 2006).

Besides this, emulsions apparent consistency was notably different and nanoemulsion showed to be apparently less consistent than macroemulsion. This particular property gave to nanoemulsion a remarkable touch, often appreciated in cosmetics products. According to Tadros (2004), in personal care applications, emulsions need a certain consistency that can provide good spreading and good skin feel. For this reason, the consistency of an emulsion is an important parameter and usually is assessed by panels for acceptability (Tadros, 2004).

Finally, both emulsions were homogeneous and equally stable under room temperature $\left(22.0 \pm 2.0^{\circ} \mathrm{C}\right)$ for at least 48 hours. After this time, only nanoemulsion 
was stable and remained so for more than 90 days, under the same conditions. As Capek (2004) has described, emulsions are thermodynamic unstable systems and their stability are merely kinetic. As they are metastable systems, they can remain stable for a long period of time if not disturbed. Their structures depend on the preparation process and steric stabilization, especially when using nonionic surfactant and/or polymers. The small particle size of nanoemulsions, if compared to macroemulsions, provides them more kinetic stability, avoiding creaming and coalescence. In the first case, Brownian motion overcomes the creaming rates induced by gravitational forces. And in the second case, the thickness of film interface (compared to particle size) avoids decreasing of it, which would lead to disruption and coalescence of the particles (Fernandez et al., 2004; Tadros et al., 2004; Tadros, 2004).

In cosmetics applications, a series of demands is important when formulating a product. Primarily, they must offer a pleasing appearance to the original formulation, and retain this appeal during storage. It means that they should remain stable for a long period of time over a wide range of temperatures. Cosmetic products are also supposed to give an agreeable feeling during application, and for this reason, emulsions should have the right consistency (rheology) to achieve this pleasant feeling, and provide long-term beneficial effects to the skin properties (Chappat, 1994; Al-Bawab, Friberg, 2006).

Nanoscience is the study of phenomena and manipulation of material at atomic, molecular and macromolecular scales, where properties differ significantly from those at a larger scale (The Royal Society and Academy of Engineering, 2004; European Commission, 2012). A present convention for nanoscale materials are materials comprised of structures in the length scale of approximately $1-100 \mathrm{~nm}$ range, having novel properties in function of their small size (National Science Foundation, 2000). Regarding nanoemulsions, current publications have pointed out their different properties (e.g. bluish brightness, flow and kinetic stability) and shown some flexibility when defining the size of particles. In this sense, Mei and colleagues (2011) as well as Izquierdo and colleagues (2005) have described nanoemulsions as systems with droplet sizes in nanometer range, whereas Calderó and colleagues (2011) have described that nanoemulsions are emulsions with droplet sizes in the range of $20-500 \mathrm{~nm}$, Solan and colleagues (2005) have described its droplet sizes in the range of 20-200 $\mathrm{nm}$ and for Bouchemal and colleagues (2004) nanoemulsions are fine dispersions having droplet covering the size range of 100-600 nm. Furthermore, according to Mason and colleagues (2006), in general, it is applied more flexible definition of a nanoemulsion in which the majority of droplets are below $100 \mathrm{~nm}$.

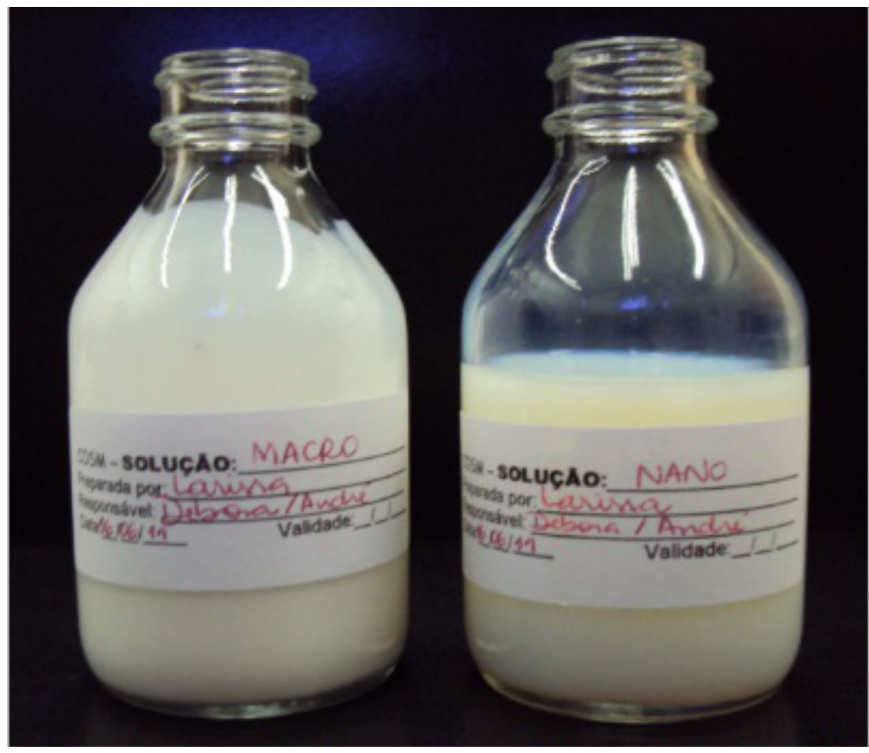

FIGURE 1 - Macroemulsion (left side) with milky aspect and Nano emulsion (right side) with bluish brightness.

Acoustic and electroacoustic spectroscopies are developing rapidly as an alternative to light-scattering methods. Both techniques are based on a well-established scientific background (Dukhin, Goetz, 1998). In both methods, the interaction of sound with the dispersed particles provides useful information. However, the set of measured parameters is different. In acoustic spectroscopy it is measured the attenuation and/or sound speed whereas for electroacoustic spectroscopy it is either the colloid vibration potential/current or the electro sonic amplitude. Acoustic spectroscopy based on the attenuation measurement does not require any assumptions on electro surface properties. As a result, the particle size distribution (PSD) obtained with acoustic spectroscopy is more reliable than that extracted from electroacoustic spectra. This means that acoustic spectroscopy is preferable for the characterization of particle size distribution (Dukhin, Goetz, 1998).

Based on the combined effect of absorption and scattering of acoustic energy, an acoustic sensor measures the attenuation frequency spectra in the sample. The sensor uses two identical piezoelectric transducers, separated by an adjustable gap that is controlled by a stepping motor. The gap between the transmitter and receiver can be adjusted in steps. In default, the gap changes from $0.15 \mathrm{~mm}$ up to $20 \mathrm{~mm}$ in 21 logarithmic steps. The basic frequency of pulse changes in steps at the same time. The frequency changes, in default, from 3 to $100 \mathrm{MHz}$ in 18 logarithmic 
steps. The number of pulses collected for the each gap and frequency step is automatically adjusted to reach a target signal-to-noise ratio. An analysis program calculating the particle size distribution (PSD) from attenuation spectra has been developed by the manufacturer. This program automatically searches the best-fit PSD and tests normal, log-normal and bimodal particle size distributions (Sun et al., 2006; Dukhin et al., 2001; Dukhin, Goetz, 2002). A single particle size measurement can be rapidly completed in less than $8 \mathrm{~min}$ (Sun et al., 2006). The typical particle size for such analysis ranges from $10 \mathrm{~nm}$ to $3 \mathrm{~mm}$, although particles outside this range have also been successfully measured (International Organization for Standardization, 2006). In addition, no calibration with the known particle size is needed (Dukhin, Goetz, 2002).

Thus, a bimodal particle size distribution (PSD) of the evaluated nano and macroemulsion is showed in Figure 2 and 3 respectively. The density distribution (on Y-axis) is on the weight basis.

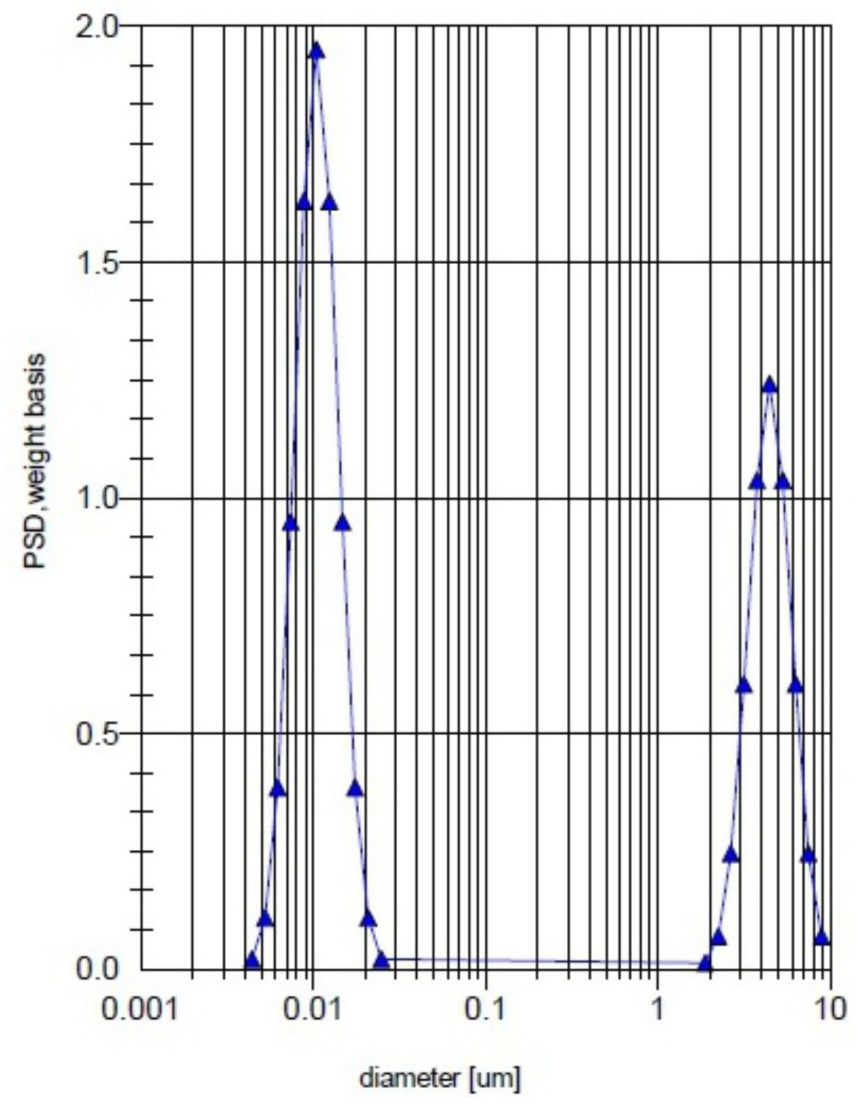

FIGURE 2 - Particle size distribution (PSD) of nanoemulsion. Bimodal PSD profile with average (mean) sizes located around $10 \mathrm{~nm}(61 \%)$ and $4.5 \mu \mathrm{m}(39 \%)$.

Assayed nanoemulsion (Figure 2) presented bimodal particle size distribution (PSD) with average (mean) sizes located around $10 \mathrm{~nm}(61 \%)$ and $4.5 \mu \mathrm{m}(39 \%)$. Standard deviation was 0.13 . In general, particles can be designated monodisperse if the standard deviation is less than 0.10 (Sun et al., 2006). It means that evaluated nanoemulsion particles were polydisperse with majority in the nano-domain $(\sim 10 \mathrm{~nm})$, which is in accordance with the definition described by Mason and colleagues (2006) and that also can explain the bluish brightness aspect.

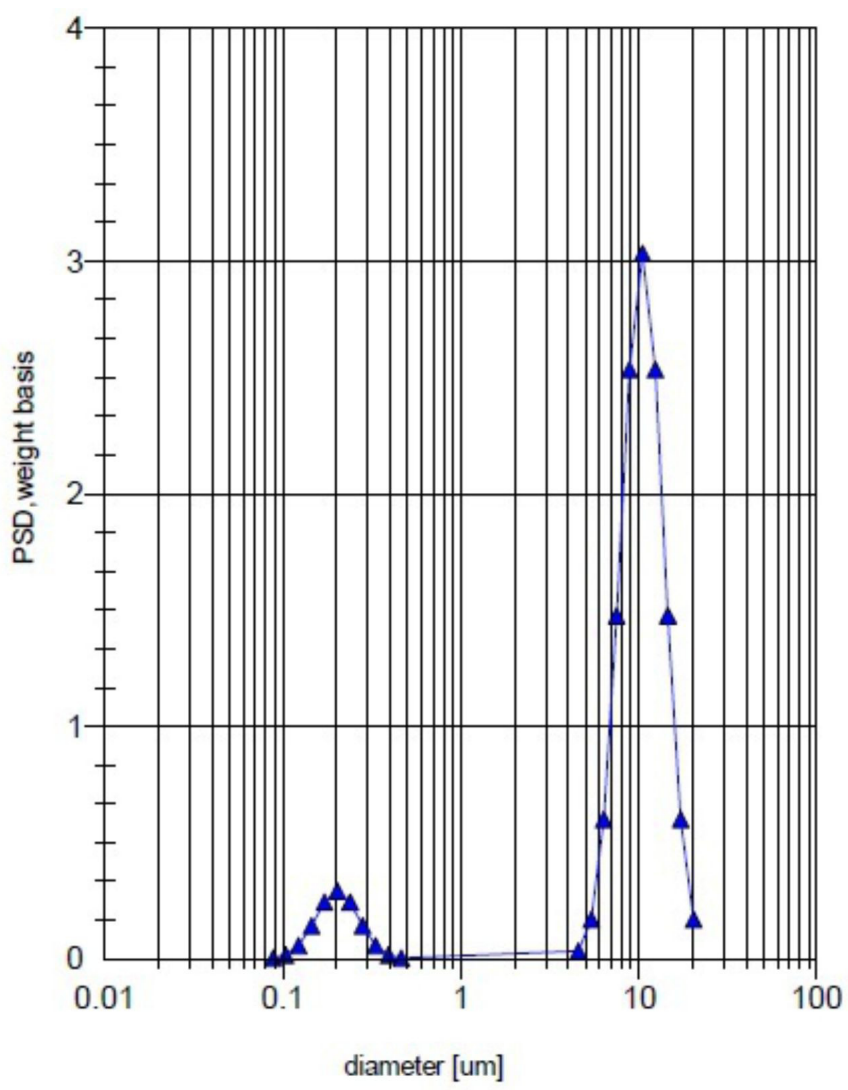

FIGURE 3 - Particle size distribution (PSD) of macroemulsion. Bimodal PSD profile with average (mean) sizes located around $202 \mathrm{~nm}(9 \%)$ and $10.4 \mu \mathrm{m}(91 \%)$.

Macroemulsion (Figure 3) showed bimodal particle size distribution (PSD) and an average (mean) sizes located around $202 \mathrm{~nm}(9 \%)$ and $10.4 \mu \mathrm{m}$ (91\%). Standard deviation was 0.12 . This means that evaluated macroemulsion particles were polydisperse with majority in the micron-domain $(\sim 10.4 \mu \mathrm{m})$, and according to Mason and colleagues (2006) it can explains the milk appearance.

Based on the results discussed above, evaluated emulsions were physically characterized. The nanoemulsion showed a bluish brightness and homogeneous appearance, remarkable touch with apparently less consistency than macroemulsion, stability longer than 48 hours under room temperature $\left(22.0 \pm 2.0^{\circ} \mathrm{C}\right)$ and bimodal PSD profile with 
average (mean) size around $10 \mathrm{~nm}(61 \%)$ and $4.5 \mu \mathrm{m}$ (39\%). Macroemulsion showed milky and homogeneous appearance, greater consistency than nanoemulsion, instability after 48 hours under room temperature $\left(22.0 \pm 2.0^{\circ} \mathrm{C}\right)$ and bimodal PSD profile with average (mean) size around $202 \mathrm{~nm}(9 \%)$ and $10.4 \mu \mathrm{m}(91 \%)$.

The Sun Protection Factor (SPF), which appears as a numeric label on suncare products, is the universal indicator of the photoprotective performance of sunscreens against UVB radiation. It is generally determined in vivo in a group of volunteers by the ratio of the least amount of ultraviolet energy required to produce a minimal erythema on a sunscreen protected skin to the amount of energy required to produce the same erythema on an unprotected skin. In this way, SPF indicates the ability of a sunscreen product to reduce UV-induced erythema (Hupel et al., 2011). Actually, the United States (FDA) method (Food and Drug Administration, 1999) and the European (Colipa) method (Comité de Liaison des Industries de la Parfumerie, 2006) are the most widely used in vivo procedures for its measurement.

However, in vitro testing methods have also been developed because they are more rapid, less expensive and above all because they prevent the involvement of human volunteers with the related ethical problems. These methods consist either in the measurement of the spectral transmittance of the sunscreen substance incorporated in a cream emulsion and applied on a synthetic support simulating the human skin (Comité de Liaison des Industries de la Parfumerie, 2007) or in spectrophotometric analysis of dilute solutions of sunscreen products (Dutra et al., 2004; Azevedo et al., 1999). The SPF is determined by mathematical equations after running UV spectra of the sunscreen absorbing film or solution in the spectral limits conventionally accepted by photobiologists and dermatologists for SPF determinations, i.e. from 290 to $400 \mathrm{~nm}$ (Hupel et al., 2011).

In this study, in vitro sun protection assessment of each emulsion, nano and macro, was measured in a spectrophotometer equipped with an integrating sphere detector (Ultraviolet Transmittance Analyzer, UV2000S, Labsphere, US) illustrated in Figure 4.

In a spectrophotometer, a ray of light incident onto a sunscreen sample will often be scattered. Light that is not transmitted is reflected or absorbed. The ratio of the total transmitted light to the total incident light is known as the transmittance, a measurable quantity. Total hemispherical transmittance is measured by the use of an integrating sphere to collect the light scattered at all angles. A photodetector responds proportionally to the internal illumination produced on the sphere wall (Springsteen et al., 1999).

The UV absorbance spectra of nanoemulsion (Figure 5) and macroemulsion (Figure 6) were obtained by measuring parameters previously established, at nine different sites on the substrate. Obtained UV absorbance spectra, express the relation between absorbance and wavelength in the range from 290 to $440 \mathrm{~nm}$.

In accordance with nanoemulsion UV spectra (Figure 5), most of the radiation was absorbed between 290 and $345 \mathrm{~nm}$. An abruptly decreasing spectra after $320 \mathrm{~nm}$ showed that most of this absorbed radiation was into the UVB range (290-320 $\mathrm{nm})$, whereas a minority part into the UVA range (320-400 $\mathrm{nm})$. For sun protection assessment purposes, the amount of radiation absorbed in the UVB range is expressive, which means that evaluated nanoemulsion was effective to absorb only the UVB radiation.

In accordance with macroemulsion UV spectra (Figure 6), most of the radiation was absorbed between

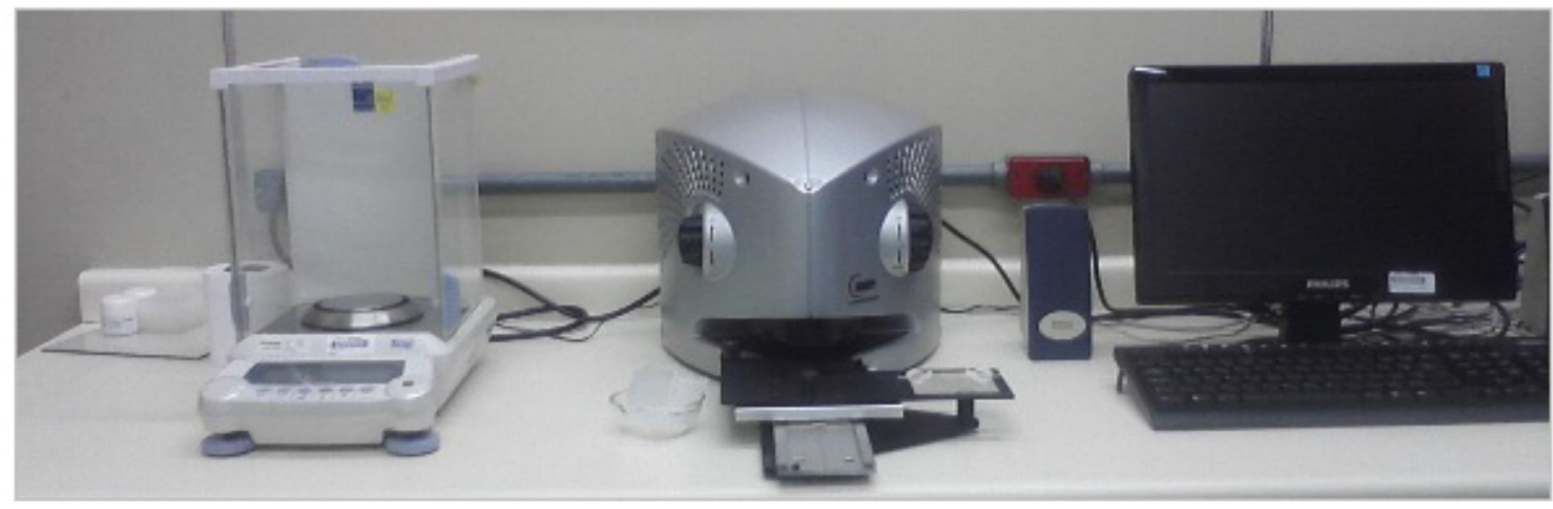

FIGURE 4 - Spectrophotometer equipped with an integrating sphere detector (Ultraviolet Transmittance Analyzer, UV2000S, Labsphere, US) used for in vitro sun protection assessment of nano and macro emulsions (Laboratory of Cosmetology, University of São Paulo). 


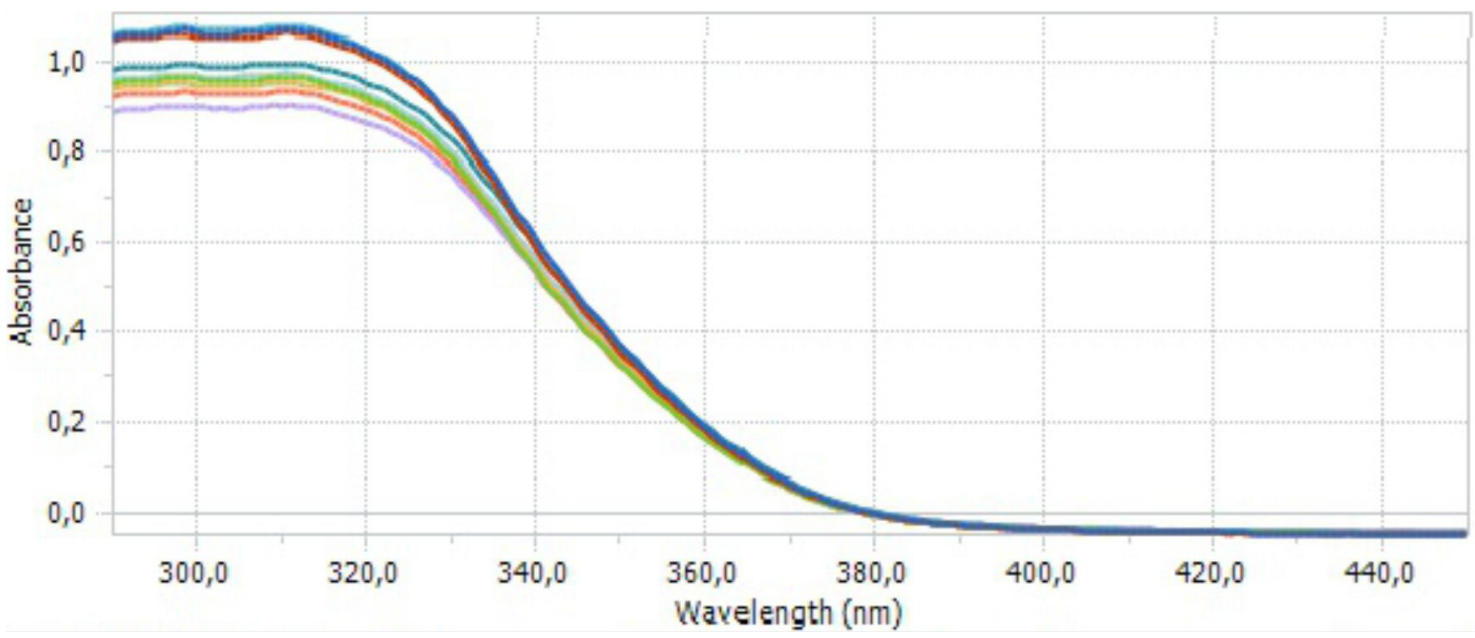

FIGURE 5 - Nanoemulsion UV absorbance spectra. It shows the UV absorbance in the UVB range (290-320 nm) and UVA range (320-400 nm) at nine different sites on the substrate.

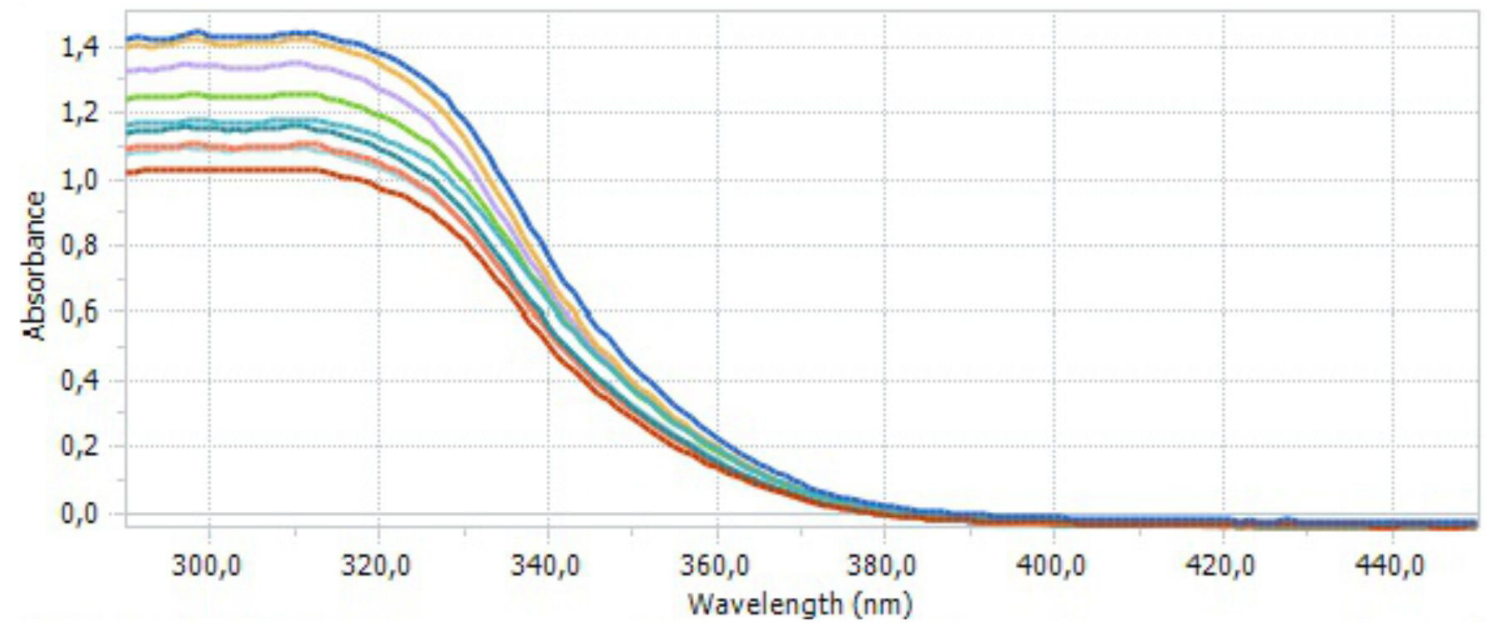

FIGURE 6 - Macroemulsion UV absorbance spectra. It shows the UV absorbance in the UVB range (290-320 nm) and UVA range (320-400 nm) at nine different sites on the substrate.

290 and $344 \mathrm{~nm}$. An abruptly decreasing spectra after $320 \mathrm{~nm}$ showed that most of this absorbed radiation was into the UVB range (290-320 nm), whereas a smaller part into the UVA range (320-400 $\mathrm{nm}$ ). Thus, macroemulsion was effective to absorb only the UVB radiation.

The UVA and UVB radiation are responsible for the balance between activation and inhibition of antioxidant systems by different mechanisms, resulting in the change in skin homeostasis. The UVB radiation is responsible for immediate damage caused by solar radiation due to its high energy, while the UVA radiation induces a series of cellular changes involving fibroblasts and melanocytes due to its higher penetration through the skin (Flora, Ferguson, 2005).

The UVB radiation is responsible for $80-90 \%$ of the sunburn. In this respect, the SPF measuring erythema induction is a factor that measures mainly the UVB protection of a sunscreen formulation (Maier, Korting, 2005).

The spectral transmittance of a sunscreen in the ultraviolet (UV) spectral range can be used to predict an in vitro SPF value. In the same way, critical wavelength $(\lambda c)$ and UVA/UVB ratio to categorize the effectiveness of UVA absorbers are also performed from spectrophotometric data (Springsteen et al., 1999).

Thus, from the obtained absorbance spectrum of nanoemulsion (Figure 5) and macroemulsion (Figure 6), average values of in vitro SPF, critical wavelength $(\lambda \mathrm{c})$ and UVA/UVB ratio were automatically calculated by the equipment and results are presented in Table II.

By definition, SPF is determined in vivo as the increase in exposure time required to induce erythema. However, measuring the spectral transmittance at UV wavelengths from 290 to $400 \mathrm{~nm}$ is a common in vitro 
TABLE II - Measured parameters for in vitro sun protection assessment of nano and macro emulsions

\begin{tabular}{lccc}
\hline Emulsion & in vitro $\boldsymbol{S P F}$ & $\boldsymbol{\lambda} \mathbf{c}$ & $\begin{array}{c}\mathrm{UVA} / \mathrm{UVB} \\
\text { ratio }\end{array}$ \\
\hline Nano & $8.0 \pm 0.9$ & $345.0 \pm 0.4$ & 0.304 \\
Macro & $12.0 \pm 3.0$ & $344.0 \pm 0.8$ & 0.282 \\
\hline
\end{tabular}

Legend: $\mathrm{SPF}=$ sun protection factor; $\lambda \mathrm{c}=$ critical wavelength

technique to estimate the SPF value (Diffey, Robson, 1989). In this technique, calculation is automatically performed by the equipment (Equation 1).

$$
S P F=\frac{\int \begin{array}{l}
400 \mathrm{~nm} \\
290 \mathrm{~nm}
\end{array} E_{\lambda} S_{\lambda} d_{\lambda}}{\int \begin{array}{l}
400 \mathrm{~nm} \\
290 \mathrm{~nm}
\end{array} E_{\lambda} S_{\lambda} T_{\lambda} d_{\lambda}}
$$

EQUATION 1 - Sun protection factor.

Where $E_{\lambda}$ is the erythemal spectral effectiveness, $S_{\lambda}$ the solar spectral irradiance and $T_{\lambda}$ is the spectral transmittance of the sample (Springsteen et al., 1999). In this study, average in vitro SPF was $8.0 \pm 0.9$ for nanoemulsion and $12.0 \pm 3.0$ for macroemulsion. It meant that evaluated nano and macroemulsions have similar in vitro SPF.

A recent concern with SPF rating system for sunscreens is that it is based on erythema as an endpoint. The UVA/UVB ratio is an indicator to describe the UVA protection offered in addition to the SPF. To calculate this parameter, the spectral transmittance values, $T_{\lambda}$, are converted to spectral absorbance values $A_{\lambda}=-\log \left(T_{\lambda}\right)$. A term named "UVA ratio" is automatically calculated, which is the ratio of the total absorption in the UVA in relation to that in the UVB (Equation 2) (Springsteen et al., 1999).

$$
\frac{a U V A}{a U V B}=\frac{\int \begin{array}{l}
400 \mathrm{~nm} \\
320 \mathrm{~nm}
\end{array} A_{\lambda} d_{\lambda}}{\int \begin{array}{l}
320 \mathrm{~nm} \\
290 \mathrm{~nm}
\end{array} A_{\lambda} d_{\lambda}}
$$

EQUATION 2 - UVA/UVB ratio.

The potential of UVA protection is classified according to the value of UVA/UVB ratio, as follows: "Too low" $(<0.2)$, "Moderate" $(0.2$ to $<0.4)$, "Good" $(0.4$ to $<0.6)$, "Superior" $(0.6$ to $<0.8)$, "Maximum" $(\geq 0.8)$ (Springsteen et al., 1999).

In this study, average UVA/UVB ratio was 0.304 for nanoemulsion and 0.282 for macroemulsion. So, according to the classification from Springsteen and colleagues (1999), it meant that both emulsions, nano and macro, have a "moderate" UVA protection, not reaching broad-spectrum protection.

An alternative parameter to indicate if the product does offer broad-spectrum protection is based on a number called critical wavelength $(\lambda \mathrm{c})$, which is determined spectrophotometrically from the absorbance spectra. To obtain this number, its spectral transmittance is measured, $T_{\lambda}$, and converted to spectral absorbance values $A_{\lambda}=-\log \left(T_{\lambda}\right)$. A ratio is automatically calculated as follows, which determines the total absorption in incremental wavelength bands and compares it to the total UV absorption. The ratio recorded for each wavelength, $\lambda$, is demonstrated in Equation 3.

$$
R=\frac{\int \frac{\lambda}{290 \mathrm{~nm}} A_{\lambda} d_{\lambda}}{\int 400 \mathrm{~nm} A_{\lambda} d_{\lambda}}
$$

EQUATION 3 - Critical wavelength (nm).

The critical wavelength $(\lambda c)$ corresponds to $90 \%$ or more from the integral curve of absorbance. The potential of UVA protection are described as "intermediate" $(340<\lambda \mathrm{c}<370 \mathrm{~nm})$ and "broad-spectrum" $(\lambda \mathrm{c}>370 \mathrm{~nm})$ (Springsteen et al., 1999).

In this study, average critical wavelength $(\lambda c)$ was $345.0 \pm 0.4$ for nanoemulsion and $344.0 \pm 0.8$ for macroemulsion. According to the classification from Springsteen and colleagues (1999), it meant that both emulsions, nano and macro, have an "intermediate" UVA protection, not reaching broad-spectrum protection.

Based on results obtained from in vitro sun protection assessment (Table II), the effectiveness profile of sunscreen formulations remained apparently similar. Nanoemulsion average in vitro SPF was $8.0 \pm 0.9$, UVA/UVB ratio was 0.304 and critical wavelength $(\lambda \mathrm{c})$ was $345.0 \pm 0.4$. Macroemulsion average in vitro SPF was $12.0 \pm 3.0, \mathrm{UVA} / \mathrm{UVB}$ ratio was 0.282 and critical wavelength $(\lambda \mathrm{c})$ was $344.0 \pm 0.8$.

\section{CONCLUSIONS}

In this study results demonstrated that evaluated sunscreens, nano and macroemulsion, have different appearance and particle sizes distribution (PSD). Nanoemulsion showed bluish brightness appearance, less apparent consistency than macroemulsion, stability longer 
than 90 days under room temperature $\left(22.0 \pm 2.0{ }^{\circ} \mathrm{C}\right)$ and bimodal PSD profile with average (mean) size around $10 \mathrm{~nm}(61 \%)$ and $4.5 \mu \mathrm{m}(39 \%)$. Macroemulsion showed cloudy milky appearance, higher consistence than nanoemulsion, instability after 48 hours under room temperature $\left(22.0 \pm 2.0^{\circ} \mathrm{C}\right)$ and bimodal PSD profile with average (mean) size around $202 \mathrm{~nm}(9 \%)$ and $10.4 \mu \mathrm{m}$ $(91 \%)$.

Results obtained from in vitro sun protection assessment showed that effectiveness profile of sunscreen formulations remained apparently similar. Average in vitro SPF was $8.0 \pm 0.9$ for nanoemulsion and $12.0 \pm 3.0$ for macroemulsion. The mean Average values of UVA/UVB ratio were 0.304 for nanoemulsion and 0.282 for macroemulsion. Finally, average values of critical wavelength $(345.0 \pm 0.4$ for nanoemulsion and $344.0 \pm 0.8$ for macroemulsion) demonstrated, according to the literature, an intermediate UVA protection, not reaching broad-spectrum protection.

\section{ACKNOWLEDGMENTS}

FAPESP (2008/57800-0) and CAPES for financial support.

\section{REFERENCES}

AL-BAWAB, A.; FRIBERG, S.E. Some pertinent factors in skin care emulsion. Adv. Colloid. Interface, v.123-126, p.313-322, 2006.

AZEVEDO, J.S.; VIANA JR., N.S.; VIANNA SOARES, C.D. UVA/UVB sunscreen determination by second-order derivative ultraviolet spectrophotometry. Farmaco, v.54, n.9, p.573-578, 1999.

BONACUCINA, G.; CESPI, M.; PALMIERI, G.F. Evaluation of dissolution kinetics of hydrophilic polymers by use of acoustic spectroscopy. Int. J. Pharm., v.377, p.153-158, 2009.

BOUCHEMAL, K.; BRIANÇON, S.; PERRIER, E.; FESSI, H. Nano-emulsion formulation using spontaneous emulsification: solvent, oil and surfactant optimization. Int. J. Pharm., v.280, p.241-251, 2004.

BRAZIL. Agência Nacional de Vigilância Sanitária. Resolução $\mathrm{n}^{\circ} 47$, de 16/03/2006. Lista de filtros ultravioletas permitidos para produtos de higiene pessoal, cosméticos e perfumes. Available at: <www.anvisa.gov.br. $>$. Accessed on: 16 jun. 2011.
CALDERÓ, G.; GARCÍA-CELMA, M.J.; SOLANS, C. Formation of polymeric nano-emulsion by a low-energy method and their use for nanoparticle preparation. J. Colloid Interface Sci., v.353, p.406-411, 2011.

CAPEK, I. Degradation of kinetically-stable o/w emulsions. Adv. Colloid Interface, v.107, p.125-155, 2004.

CHAPPAT, M. Some applications of emulsions. Colloid Surface A, v.91, p.57-77, 1994.

COMITÉ DE LIAISON DES INDUSTRIES DE LA PARFUMERIE. COLIPA. Guidelines for international sun protection factor test method. 2006. Available at: $<$ http:// www.colipa.eu>. Accessed on: 21 mar. 2011.

COMITÉ DE LIAISON DES INDUSTRIES DE LA PARFUMERIE. COLIPA. Method for the in vitro determination of UVA protection provided by sunscreen products. 2007. Available at: <http://www.colipa.eu> Accessed on: 17 set. 2011.

COUTEAU, C.; FAURE, A.; FORTIN, J.; PAPARIS, EVA.; COIFFARD, L.J.M. Study of the photostability of 18 sunscreens in creams by measuring the SPF in vitro. $J$. Pharm. Biomed., v.44, p.270-273, 2007.

DIFFEY, B.L.; ROBSON J. A new substrate to measure sunscreen protection factors throughout the ultraviolet spectrum. J. Soc. Cosmet. Chem., v.40, p.127-133, 1989.

DUKHIN, A.S.; GOETZ, P.J. Characterization of aggregation phenomena by means of acoustic and electroacoustic spectroscopy. Colloid Surface A, v.144, p.49-58, 1998.

DUKHIN, A.S.; GOETZ, P.J.; TRUESDAIL, S. Titration of concentrated dispersions using electroacoustic zeta potential probe. Langmuir, v.17, p.964-968, 2001.

DUKHIN, A.S.; GOETZ, P.J. Ultrasound for characterizing colloids: particle sizing, zeta potential, rheology. New York: Elsevier Science, 2002. 372 p.

DUTRA, E.A.; OLIVEIRA, D.A.G.C.; KEDORHACKMANN, E.R.M.; SANTORO, M.I.R.M. Determination of sun protection factor (SPF) of sunscreens by ultraviolet spectrophotometry. J. Pharm. Sci., v.40, n.3, p.381-38, 2004. 
EE, S.L.; DUAN, X.; LIEW, J.; NGUYEN, Q.D. Droplet size and stability of nano-emulsions produced by the temperature phase inversion method. Chem. Eng. J., v.140, p.626-631, 2008.

EUROPEAN COMMISSION. Introduction to nanotechnologies. 2009. Available at: <http://ec.europa.eu/nanotechnology/ index_en.html>.Accessed on: 29 may 2012.

EUROPEAN ECONOMIC COMMUNITY. EEC. Council directive 76/768/EEC of 27/07/1976 on the approximation of the laws of the member states relation to cosmetic products. Available at: <eur-lex.europa.eu/LexUriServ/ LexUriServ.do?uri=CONSLEG:1976L0768:20110603:E N:PDF.>. Accessed on: 14 nov. 2011.

FERNANDEZ, P.; ANDRÉ, V.; RIEGER, J.; KUHNLE, A. Nano-emulsion formation by emulsion phase inversion. Colloid Surface A, v.251, p.53-58, 2004.

FERRERO, L.; PISSAVINI, M.; DEHAIS, A.; MARGUERIE, S.; ZASTROW, L. Importance of substrate roughness for in vitro sun protection assessment. IFSCC Magazine, v.9, p.2-13, 2006.

FERRERO, L.; PISSAVINI, M.; DOUCET, O. How a calculated model of sunscreen film geometry can explain in vitro and in vivo SPF variation. Photochem. Photobiol. Sci., v.9, p.540-551, 2010.

FLORA, S.; FERGUSON, L.R. Overview of mechanisms of cancer chemopreventive agents. Mutat. Res., v.591, p.8$15,2005$.

FOOD AND DRUG ADMINISTRATION. FDA. Sunscreen drug products for over-the-counter human use - Final monograph. Federal Register, v.64, p.27666-27693, 1999.

FRONZA, T.; GUTERRES, S.; POHLMANN, A.; TEIXEIRA, H. Nanocosméticos: em direção ao estabelecimento de marcos regulatórios. Porto Alegre: Gráfica da UFRGS, 2007. 64 p.

HUPEL, M.; POUPART, N.; GALL, E.A. Development of a new in vitro method to evaluate the photoprotective sunscreen activity of plant extracts against high UVB radiation. Talanta, v.86, p.362-371, 2011.
I N T E R N A T I O N A L O R G A N I Z A T I O N F O R STANDARDIZATION. Measurement and characterization of particles by acoustic methods - Part 1: Concepts and procedures in ultrasonic attenuation spectroscopy. ISO 20998-1. 2006. Available at: <www.iso.org >. Accessed on: 14 aug. 2011.

IZQUIERDO, P.; FENG, J.; ESQUENA, J.; TADROS, T.F.; DEDEREN, J.C.; GARCIA, M.J.; AZEMAR, N.; SOLANS, C. The influence of surfactant mixing ratio on nano-emulsion formation by the pit method. J. Colloid Interface Sci., v.285, p.388-394, 2005.

MAIER, T.; KORTING, H.C. Sunscreens: which and what for? Skin Pharmacol. Physiol., v.18, p.253-262, 2005.

MASON, T.G.; WILKING, J.N.; MELESON, K.; CHANG, C.B.; GRAVES, S.M. Nanoemulsions: formation, structure, and physical properties. J. Phys.-Condens. Matter., v.18, p.635-666, 2006.

MEI, Z.; XU, J.; SUN, D. O/W nano-emulsions with tunable PIT induced by inorganic salts. Colloid Surface A, v.375, p.102-108, 2011.

NATIONAL SCIENCE FOUNDATION. Nanotechnology definition. 2000. Available at: <http://www.nsf.gov/ crssprgm/nano/reports/omb_nifty50.jsp > . Accessed on: 04 mar. 2010.

PAT TA N A A R G O N, S.; M UNH A P O L, T.; HIRUNSUPACHOT, P.; LUANGTHONGARAM. Photoisomerization of octyl methoxycinnamate. $J$. Photochem. Photobiol. A, v.161, p.269-274, 2004.

PISSAVINI, M.; FERRERO, L.; ALARD, V.; HEINRICH, U.; TRONNIER, H.; KOCKOTT, D.; LUTZ, D.; TOURNIER, V.; ZAMBONIN, M.; MELONI, M. Determination of the in vitro SPF. Cosmet. Toiletries, v.118, p.63-72, 2003.

SCHAUDER, S.; IPPEN, H. Contact and photocontact sensitivity to sunscreens. Review of a 15-year experience and of the literature. Contact Dermatitis, v.37, p.221-232, 1997.

SOLANS, C.; IZQUIERDO, P.; NOLLA, J.; AZEMAR, N.; GARCIA-CELMA, M.J. Nano-emulsions. Curr. Opin. Colloid Interface Sci., v.10, p.102-110, 2005. 
SPRINGSTEEN, A.; YUREK, R.; FRAZIER, M.; CARR, K.F. In vitro measurement of sun protection factor of sunscreens by diffuse transmittance. Anal. Chim. Acta, v.380, p.155164, 1999.

SUN, Y-P.; LI, X.; CAO, J.; ZHANG, W.; WANG, H.P. Characterization of zero-value iron nanoparticles. $A d v$. Colloid Interface, v.120, p.47-56, 2006.

TADROS, T. Application of rheology for assessment and prediction of the long-term physical stability of emulsions. Adv. Colloid Interface, v.108-109, p.227-258, 2004.

TADROS, T.; IZQUIERDO, P.; ESQUENA, J.; SOLANS, C. Formation and stability of nano-emulsions. Adv. Colloid Interface, v.108-109, p.303-318, 2004.
THE ROYAL SOCIETYAND ACADEMY OF ENGINEERING.

Nanoscience and nanotechnologies: opportunities and uncertainties. 2004. Available at: < http://www.nanotec. org.uk/finalreport.htm>. Accessed on: 09 may 2010.

VELASCO, M.V.R.; SARRUF, F.D.; SALGADO-SANTOS, I.M.N.; HAROUTIOUNIAN-FILHO, C.A.; KANEKO, T.M.; BABY, A.R. Broad spectrum bioactive sunscreens. Int. J. Pharm., v.363, p.50-57, 2008.

Received for publication on $22^{\text {nd }}$ December 2012 Accepted for publication on $16^{\text {th }}$ February 2013 
